\section{Agriculture at the}

$A^{S}$ was to be expected in an important agricultural district such as Edinburgh, the meetings of the Agricultural Section created a good deal of interest, and were well attended throughout the whole of the meeting.

One or two departures from the usual routine have to be noted. Dr. E. J. Russell, of Rothamsted, delivered a popular address to farmers on "Science and Crop Production " on the day betore the formal work of the section began. There was a large attendance from the district, including many representative farmers, and the address was much appreciated. A report of Dr. Russell's address has already appeared in NATURE of September 22, p. ri6. The second change was that the presidential address, instead of being read at the opening meeting, was circulated amongst the members. At the meeting on Monday, September 12, the president, Mr. C. S. Orwin, gave an abstract of his address, which was followed by a most useful discussion.

The number of papers offered to the committee was almost embarrassingly large; they were grouped, so far as possible, according to subject. On the opening day they dealt mostly with soil problems. Dr. Winifred E. Brenchley spoke on "The Effect of Longcontinued Manuring of Grassland," and described the results of experiments which had been carried out at Rothamsted on permanent meadow-land for a period of sixty-six years-long enough to allow a true estimate to be made of the effect of the different fertilisers apart from the influences of season. The effects of complete manuring, one-sided manuring, no manure, and of lime were considered in detail. Dr. W. G. Smith discussed "Methods of Gra sland Analyses," and described the results obtained from plots laid down with various grass mixtures in r914. The plots were analysed annually, and figures were given showing the composition of the plots now as compared with what was laid down.

Dr. W. G. Smith and Dr. A. Lauder gave the results of a soil survey which had been carried out in the Lothians. More than roo square miles have been surveyed and the vegetation recorded on 6-in. survey maps. Definite relations have been established between the types of vegetation and the productivity of the holdings, and simple methods of improving the grass were described. Dr. Lauder directed attention to the relation between the amount of organic matter and the lime requirement of the soila connection which had been noticed by other workers. Mr. M. M. Monie gave an account of a photographic survey of soils which he had carried out in the west of Scotland. His paper was illustrated with an excellent series of lantern-slides, and the method he proposes, while of limited use by iiself, should have a useful place in soil-survey work.

Prof. Hendrick dealt with "The Absorption and Retention of Manurial Substances by Granitic Soils." These soils are free from carbonate of lime, have a slightly acid reaction, and a high lime requirement. Notwithstanding these conditions, it was found that, even in very heavy dressings, ammonia was almost completely fixed and an equivalent quantity of nitrates recovered in the drainage. The phosphate was also completely retained. The potash was less firmly held, and in the later periods of the experiment the retention was very slight.

Mr. H. J. Page and Mr. H. G. Thornton contributed an important paper on "The Rapid Fluctuations in Bacterial Numbers and Nitrate Content of Field Soil and their Interrelation."

On Friday the papers dealt largely with dairying NO. 2723 , VOL. IOG]

\section{British Association.}

problenıs. Prof. K. A. Berry dealt with the important commercial question of "The Production and Utilisation of Whey." He showed that on a moderate estimate the amount of whey produced annually is worth $337,000 l$. He emphasised the great loss involved under the present methods of disposal, where large quantities are allowed to run to waste, and discussed the possibility of new methods of utilisation. In addition to pig-feeding, the possibility of preparing milksugar and whey powders was considered.

Prof. R. H. Leitch described the recent work he had carried out with starters in cheese-making, as well as experiments in the manufacture of rennet, methods of standardising rennet extracts, and some new developments in butter-making. Dr. W. Taylor and Mr. A. D. Husband contributed a note on "The Varying Rates of Secretion of Milk on its Percentage Composition." They come to the conclusion that the interrelationship of volume and composition may be summarised thus :-The percentages of protein, fat, and ash vary inversely, and the percentage of lactose varies directly as the daily volume of milk secreted. Two papers were contributed by Dr. Tocher, one dealing with "The Statistical Analyses of Scottish Milk Records," and another dealing with "The Methods of Determining the Significant Differences of Yield of Milk."

Prof. Hendrick described "A New Scheme for the Determination of Unexhausted Manurial Values," and dealt in particular with the question of cumulative fertility. Dr. Tocher gave the results of experiments on "The Citric Solubility of Manurial Phosphates," and concludes that citric solubility is a worthless test from the agricultural point of view. The only practical tests are:-(r) The total phosphatic content, (2) the degree of fineness of grinding, and (3) freedom from substances of an injurious character to plants.

Mr. J. Alan Murray described some recent experimental work which he had carricd out on "The Composition of Ensilage." Mr. Murray dealt with the loss involved in the making of ensilage, and considered that it was a fallacy that farmers can save money by dispensing with root crops and substituting ensilage in the rations of farm animals. He considered that it was not possible to reduce the allowance of concentrated food by substituting ensilage for roots. In the discussion which followed some exception was taken to $\mathrm{Mr}$. Murray's estimates as to the cost of producing ensilage.

The meeting on Monday was devoted to economic questions, and began with the discussion on the president's address, to which reference has already been made. Lord Bledisloe followed with a paper on "Wheat as the Basis of Britain's Food-Supply in Time of War." He pointed out the advantages of potatoes, supplemented by pig-meat, over wheat. Great Britain is self-contained in its potato requirements and an exporter, while under normal conditions she imports four-fifths of her wheat requirements from abroad. The normal production of wheat is preponderantly in the eastern counties of Great Britain (ten counties out of eighty-six provide more than half the total output), while potatoes are grown in every part of the kingdom. Many farmers are wholly unfamiliar with wheat production, and have neither the implements nor the buildings necessary for its production and storage, but every farmer, gardener, and allotment-holder knows how to grow potatoes. Then again, the wheat crop may be wholly lost for human requirements through bad weather or incendiarism. Potatoes, though subject to disease (which can be minimised by spraying), are less vulnerable, as the edible tuber is beneath the ground. Potatoes provide an 
immense quantity of starchy food, far exceeding wheat in output per acre, and the crop can be obtained in shorter time and harvested at different periods of spring, summer, and autumn. Potatoes are, however, relatively deficient in fat and protein, but these can be supplied, by way of supplement, by pig-meat. The production of pigs in war-time should, therefore, be encouraged, and not discouraged as during the late war; their capacity for rapid reproduction, large families, high percentage of fat-yield, and great variety of food products render them invaluable meat-providers in a national emergency. Grazing varieties deserve special encouragement. Another reason for the encouragement of potato-growing lies in the large areas of permanent and temporary pasture, valuable storehouses of accumulated fertility, which can be utilised in time of war when fertilisers are bound to be scarce; no crop thrives better in newly-turned pasture than potatoes. Potato-flour is also useful, for it can be converted into wholesome and palatable bread, scones, and cakes, while surplus or unsuitable potatoes can be utilised both as stock food and as the source of motor spirit, commercial starch, etc. The home production of breadstuffs in the form of potatoes will reduce to a minimum the costs and risks of marine transport, and their production in every part of the kingdom for local needs will largely reduce the strain on internal transport.

In the discussion which followed some doubt was expressed as to whether it would be wise to rely so exclusively on one crop as a source of food, especially in view of the danger of the total failure of the crop by disease.

Sir Henry Rew communicated a paper on "Agricultural Statistics: Their Collection and Use" (Journal of the Ministry of Agriculture, vol. 28, p. 636, I921); Mr. A. W. Ashby dealt with "Standards of Production in Agriculture," and Mr. Pryse Howell with "Economic Surveys of Agriculture in Wales."

On Tuesday the papers contributed dealt mostly with nutrition problems. Dr. W. E. Elliot and Mr. Arthur Crichton contributed a paper describing a series of feeding and metabolic experiments which had been conducted on pigs with the object of determining the cause of a disease variously known as "rheumatism," "cramp," or "rick ts." They conclude from the results of their experiments that the condition is produced in animals deprived of access to earth or other mixtures of minerals, and fed only on grains and certain other concentrates commonly used in pigfeeding. The inorganic constituents in these feedingstuffs do not correspond with the requirements of the growing pig, for there is a marked deficiency of calcium and an excess of acid radicles. If the mineral matter of a ration composed of these feeding-stuffs be adjusted to the reauirements of the animal by a mixture of salts compounded to correct the deficiences the disease does not occur. The addition of fat soluble $\mathrm{A}$ or of water soluble $\mathrm{C}$ to a ration that produces the condition does not prevent the onset of the symptoms. Mr. John Golding exhibited photographs of a litter of nigs from a sow which was fed on a diet deficient in vitamins; they all suffered from serious malformation of the hindquarters. In the discussion which followed exception was taken to the conclusions arrived at bv Dr. Elliot and Mr. Crichton. and it was considered by some speakers that it had not been proved that the disease in question was solely due to a deficiency in mineral matter in the ration.

Dr. T. B. Orr then gave an account of "The Application of an Indirect Method of Calorimetry to the Ruminant," and described the apparatus as adapted for experiments with goats.

Major C. C. Hirst gave a paper on "The NO. 2723 , VOL. IOG]
Genetics of Egg-production in Poultry." Major Hirst described the results of five years' experimental breeding on Mendelian lines, and showed that the first year's egg-production of a hen depends on the combined action of at least seven main genetic factors. The economic significance of the results was discussed in detail, and the effects of the old methods of grading by winter and annual records were pointed out. The new system of grading production has a double value to the practical breeder, because the descriptive somatic gradings, being based on the genetic factors concerned, give a line also to the breeding value of the bird, for the extreme grades tend to breed true. The adoption of this grading system for laying corrpetitions would lead to rapid progress in poultry-breeding, and be of educational value to poultry-keepers in general, for the winning birds would br ad winners with more frequency than they do now.

Miss Dorothy J. Jackson described an investigation which she had carried out in the genus Sitones with the object of investigating which species were injurious to leguminous crops in Britain; the lifehistory of these species has also been determined. No satisfactory method of control is at present known. In the case of the species which breed on clover control would be extremely difficult on account of their prolonged period of egg-laying, but this difficulty would not apply to the species which breed upon peas and beans. Laboratory experiments on infection with the various fungus spores of Botrytis bassiana (Balsamo), Montagne, have proved successful, death invariably occurring in from nine to thirteenth days.

In a paper by Miss M. S. G. Breeze "The Degeneration in Anthers of Potato" was discussed. 'Two definite types of degeneration have been observed:(I) Where the pollen-grains are formed, but degenerate at various stages of development, and (2) in which the pollen mother-cells are apparently normal, but no reduction division takes place. The question of the inheritance of degenerate condition of anthers was also discussed.

In addition to the formal meetings a visit was paid to the Station for Research in Animal Breeding, where a demonstration on the wools of primitive breeds of sheep was given by Dr. F. A. E. Crew. Dr. R. Stewart MacDougall had an interesting exhibit of insects injurious to stock, while in the library of the Agricultural Department there was an exhibition of early works dealing with agriculture and kindred subjects.

On the Friday afternoon the new Plant-Breeding Station at East Craigs, Corstorphine, was inspected. The party was received by Dr. C. M. Douglas, of Auchlochan, chairman of the committee, and $\mathrm{Mr}$. Drummond described the work of the station. Afterwards the farm of Mr. John Cowper at Gogar Mains was visited.

On the Saturdav a whole-dav excursion took place to typical farms in East Lothian. The concluding visits were to the well-known farms of East Barns and Barneyhill, where the party was received by Sir Harry and Lady Hope.

If a word of criticism may be indulged in, attention might be directed to the fact that few of the readers of papers seriouslv tried to confine themselves to the time allotted to them in the programme or made a real endeavour to prepare an abstract of their work suitable for presentation to the meeting. In this way the amount of time availabie for discussion was much too short. The number of papers accepted was probably rather large, but much time would have been saved had some of the readers appreciated the fact that the time at their disposal was necessarilv very limited.
A. Lauder. 